\title{
Analysis of training needs in MYPES by Dolores Hidalgo, C.I.N. GTO
}

\section{Análisis de necesidades de capacitación en MYPES de Dolores Hidalgo, C.I.N. GTO}

\author{
MEJÍA-RODRÍGUEZ, Edith Magali†**, SAN ELÍAS-CONEJO, Carla Michele and DEL ÁNGEL- \\ SALDAÑA, Beatriz
}

Universidad Tecnológica del Norte de Guanajuato, Blvd. Hidalgo 34, Universidad, 37800 Dolores Hidalgo Cuna de la Independencia Nacional, Gto. Mexico.

ID $1^{\text {st }}$ Author: Edith Magali, Mejía-Rodríguez

ID $1^{\text {st }}$ Coauthor: Carla Michele, San Elías-Conejo

ID $2^{\text {nd }}$ Coauthor: Beatriz, del Ángel-Saldaña

DOI: $10.35429 / J L D E .2019 .5 .3 .1 .6$

Received July 28, 2019; Accepted December 21, 2019

\section{Abstract}

Dolores Hidalgo CIN Gto., Has 4,996 business units of which 4,968 are SMEs, represent $99.4 \%$ (INEGI, 2016), these companies are a very important column in the economy of the municipality not only because of the activities so diverse that in them they develop, but also by generating jobs. In them it is necessary to keep staff prepared and updated to improve the performance of workers in the development and provision of quality products and services. Through the diagnosis of training needs (DNC) any type of organization can obtain information to determine what should prepare the staff, as well as develop the training programs required by the company. With local entrepreneurs, over 5 years, in collaboration with teachers and students in compliance with the academic content of the subjects of the curriculum of the career of TSU in Human Capital Area Administration, a diagnosis of the needs of staff training in companies of Dolores Hidalgo, CIN, trying to identify which are the main topics in which training is required. From 2015 to 2019, 109 training needs diagnoses (DNC) have been made on average 22 per year with the collaboration of a total of 505 students and 3 teachers of the administrative education program: human resources and human capital. The results identified a recurrence in the needs of companies and their employees to reinforce their knowledge about: safety and hygiene, communication, customer service and teamwork. It is expected from this analysis to determine which are the areas of training required by companies to propose the design of training courses, which allow to increase skills and strengthen knowledge in employees.

Diagnosis of training needs, DNC, Training courses

\section{Resumen}

Dolores Hidalgo CIN Gto., cuenta con 4,996 unidades empresariales de las cuales 4,968 son MyPEs, representan el 99.4 \% (INEGI ,2016), estas empresas son una columna muy importante en la economía del municipio no solo por las actividades tan diversas que en ellas se desarrollan, sino también por la generación de empleos. En ellas se hace necesario mantener preparados y actualizados al personal para mejorar el desempeño de los trabajadores en la elaboración y prestación de productos y servicios de calidad. Mediante el diagnóstico de necesidades de capacitación (DNC) cualquier tipo de organización puede obtener información para determinar en qué se debe preparar al personal, así como también elaborar los programas de capacitación requeridos por la empresa. Con empresarios de la localidad, a lo largo de 5 años, en colaboración con profesoras y alumnos en cumplimiento de los contenidos académicos de las materias del plan de estudios de la carrera de TSU en Administración Área Capital Humano se han realizado diagnóstico de las necesidades de capacitación del personal en empresas de Dolores Hidalgo, C.I.N., tratando de identificar cuáles son los principales temas en los que se requiere capacitación. De 2015 al 2019 se ha realizado hasta el momento 109 diagnósticos de necesidades de capacitación (DNC) en promedio 22 por año con la colaboración de un total de 505 alumnos y 3 profesoras del programa educativo de administración: recursos humanos y capital humano. En los resultados se identificó una recurrencia en las necesidades de las empresas y sus empleados la de reforzar sus conocimientos sobre: seguridad e higiene, comunicación, atención al cliente y trabajo en equipo. Se espera a partir de éste análisis determinar cuáles son las áreas de capacitación que requieren las empresas para proponer el diseño de cursos de capacitación, que permitan incrementar habilidades y fortalecer los conocimientos en los empleados.

Diagnóstico de necesidades de capacitación, DNC, Cursos de capacitación

Citation: MEJÍA-RODRÍGUEZ, Edith Magali, SAN ELÍAS-CONEJO, Carla Michele and DEL ÁNGEL-SALDAÑA, Beatriz. Analysis of training needs in MYPES by Dolores Hidalgo, C.I.N. GTO. RINOE Journal-Labor and Demographic economics. 2019. 3-5: 1-6.

\footnotetext{
* Correspondence to Author (email: edithmejia@utng.edu.mx)

$\dagger$ Researcher contributing first author.
} 


\section{Introduction}

The education in the countries has received many criticisms, the organizations indicate that the graduates do not have the skills and knowledge that the company needs for them to work effectively and efficiently, however, it must be considered that the primary objective of education must be to help people by providing knowledge and developing their skills and personality to achieve their improvement as individuals, as indicated by Siliceo, A. (2006).

Education should not only focus on the preparation of capable and competent individuals because what it seeks is the evolution of man. Within this area, training and training also has an influence on the education and training of individuals, people are unfinished beings, until the last day of their life they are in constant learning and development, so through training, training, training and development, continues with their education and training throughout their existence, in this way individuals are improving, renewing and evolving. Companies and training must assume a social responsibility, not only must they be useful to improve and obtain greater benefits, it must contribute to the training of individuals.

This is materialized in the LFT in articles $153 \mathrm{~A}$ to $153 \mathrm{X}$ where the obligation of employers to prepare workers is marked, it should be clarified that within this section if you can appreciate that social responsibility of training because it aims to raise the standard of living of the worker and his labor competency (STPS, 2012), as the training is specified as opposed to education if it is focused on preparing workers to have a better performance in their work in order to increase productivity and by therefore, the profits generated in the organization, so it is inconsistent that in these times companies do not want to invest in training because it is an expense, for example, what was born as a way to guarantee knowledge and experience for those workers that did not have a document that endorsed their preparation is also required for graduates of various ins educational qualifications the so-called certifications, in this way the companies allow the investment in the preparation to carry out their work in the organizations to be exclusively in charge of the government and the employee.
An important point to consider is that just as the environment changes, societies, countries and people, science and technology are also in that process and the educational system which tries to adapt to the advances that are presented in this area, but it is not enough, if organizations want and intend to remain at the forefront they must prepare their staff for it, they themselves are the creators, generators and developers of knowledge, techniques, technology, methods, improvement processes, etc. which represents his contribution to the advancement of science, technology and society.

In turn, to the extent that people acquire, assimilate and transfer knowledge and techniques, there is the possibility of finding more innovative and creative solutions to the problems and needs faced by companies, as it can be seen, this becomes a circle. virtuoso where they support society and in turn it gives what the organization requires to continue growing and developing.

Under this context in which it is intended to meet one of the objectives of education; Maintaining relations with the company and its relationship with the University and trying to contribute to compliance with the Federal Labor Law on training is that the process of training and staff development for organizations has begun to operate, for this purpose they have made diagnoses of training needs in these.

Dolores Hidalgo CIN Gto., Has 5051 economic units, of which 5019 are micro and small companies, representing $0.99366462086715501 \%$ (National Institute of Statistics and Geography, 2019). These companies are a very important column in the economy of the municipality not only for the activities so diverse that they develop, but for the generation of jobs and the flexibility to adapt to the changes.

The training needs diagnosis (DNC) is the procedure in which any type of organization large or small can obtain information necessary to develop a training program. The DNC is a method focused on determining which are the main needs in the performance of the activities of the organization and its employees to know which require training. 
The main objective of the DNC is to identify the discrepancies between what is and what should be in terms of training, in answering the questions of Who needs training? What do you need training? With what level of depth? When and in what order should they be trained? (González, 2001)

The way in which the MyPEs implement a DNC varies depending on the turnover, number of employees and the functional areas in which they divide and specialize the work, each administrator or business owner decides how they identify their needs and determines when it is necessary specialization in some tasks and activities that require technical knowledge.

The knowledge, skills, abilities, aptitudes and attitudes of the personnel of an organization are fundamentally those that generate an identity and can achieve a sustainable competitive advantage and likewise the lack of these could represent a conflict, so the entrepreneur must worry about generate the necessary tools that support staff to properly perform their work.

With local businessmen, over 5 years, in collaboration with the professors and students in compliance with the academic contents of the subjects of the curriculum of the TSU career in Human Capital Area Administration, a diagnosis of the needs of training of micro and small business personnel of Dolores Hidalgo, CIN, trying to identify what are the main issues in which training is required.

The objective is, based on the results obtained from the application of the DNCs during the years of 2015, 2016, 2017, 2018 and 2019 , to make a historical analysis that helps determine what are the areas of opportunity in terms of training that have the Based on this, companies define, analyze, propose and update the design of training courses that allow them to increase skills and strengthen areas of opportunity for employees.

Over the course of 5 years, the training sample event has been carried out, to carry it out, 109 diagnoses of training needs have been carried out in companies with the support of 505 students.
By reviewing the results that have been obtained from the investigations carried out, an overview of the conditions and requirements of the companies in terms of training can be obtained, in order to focus the efforts and prepare the workers and employers on issues that allow providing and develop knowledge, skills, aptitudes and attitudes that have a favorable impact on the performance of their work and on the growth and improvement of the achievement of organizational objectives. This is how once the training needs diagnoses have been made, the event of the training exhibition has been organized where students have been prepared through the subject of human capital development and integration and instructor training course 5 generations to teach courses with which workers and entrepreneurs learn new ways of operating the company, so far not only employees and employers have benefited, but also students for whom it has implied a new experience experiential of what they can get to do their work life and in turn for the university has allowed him to fulfill his social work.

\section{Objective}

Perform the analysis of training needs in the MyPEs of Dolores Hidalgo C.I.N. Gto. to provide information and guide efforts in the realization of events that strengthen the knowledge, skills, abilities, aptitudes and attitudes of workers, contributing in this way to the development of people and companies.

\section{Methodology to be developed}

To perform the analysis of the training needs of MyPEs in Dolores Hidalgo C.I.N. the actions mentioned below have been performed.

- Organization of work teams.

- Linking and formalizing the authorization with companies that approve the completion of training diagnoses.

- Pre-diagnostic study to know the general situation of the company, which facilitates the next phase.

- Design of data collection instruments.

- Collection of information or field work.

- Analysis of results. 
- Preparation and formal delivery of the DNC report.

- Development of the training program by company.

\section{Applied Tools}

To make the pre-diagnosis and diagnosis, qualitative, quantitative, mixed research, action research, documentary and field research have been used. Among the data collection instruments, observation, interview, check list, ID, questionnaire, survey, task analysis, among others, are used to state the situation in which the company is in relation to the ideal. For this case, the documentary research allowed the collection of the historical information of the results reports prepared by the professors and students of the years 2015, 2016, 2017, 2018 and 2019, in turn, the database in Google $\AA$ form is designed, the Information is collected electronically, concentrated in a database and the results are measured with tables and comparative graphs to facilitate interpretation.

\section{Results}

The project to investigate training needs has been carried out from 2015 to 2019, so far 109 training needs diagnoses (DNC) have been made on average 22 per year with the collaboration of a total of 505 students and 3 teachers of the educational administration program: human resources and human capital. The following table shows the total number of participants from both companies and students.

\begin{tabular}{|c|c|c|c|c|c|c|c|}
\hline Year & $\begin{array}{c}1 \\
2015\end{array}$ & $\begin{array}{c}2 \\
2016\end{array}$ & $\begin{array}{c}3 \\
2017\end{array}$ & $\begin{array}{c}4 \\
2018\end{array}$ & $\begin{array}{c}5 \\
2019\end{array}$ & TOTAL & average \\
\hline $\begin{array}{l}\text { \# of companies to } \\
\text { which the DNC } \\
\text { was carried out. }\end{array}$ & 22 & 21 & 25 & 20 & 21 & 109 & 22 \\
\hline $\begin{array}{l}\text { \# of students who } \\
\text { participated in the } \\
\text { gathering of } \\
\text { information. }\end{array}$ & 75 & 115 & 113 & 100 & 102 & 505 & 101 \\
\hline
\end{tabular}

Table 1 DNC historical data

Source: self made (2019)

The predominant turns of the MyPEs that have been diagnosed are: food, ceramic producers and service companies. In table 2 , the data is presented in more detail.

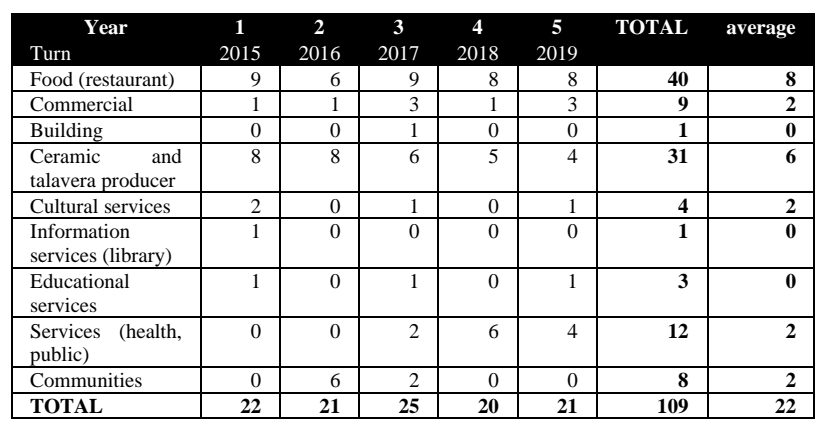

Table 2 Turn of the companies

Source: self made (2019)

\section{Results 2015}

Derived from the diagnosis made to 22 companies mainly of the food industry, there are 9 and ceramic producers that are 6 , as shown in graphic 1, the following data are obtained:

In 2015, the main need for training in the 22 participating companies is safety and hygiene measures, teamwork and customer service, although in a smaller amount they express needs for communication, accounting and motivation. Other more specific topics of the work area are: administration, excel, first aid, induction, human relations, quality of service, human development, leadership, inventories, strategic planning, pedagogical techniques. In total, they say they need 23 different topics, including those mentioned, as shown in graphic 2 .

That year the limitations for collecting the information were not documented.

\section{Results 2016}

From the diagnosis made to 21 companies of predominant turn producing ceramic with 8 companies and food 6 as can be seen in graphic 3 of Dolores Hidalgo, C.I.N., the following data are obtained: Again in companies it is necessary to train in safety and hygiene, communication, customer service, teamwork and motivation as in the previous year, as shown in graphic 4. Among the main limitations found to obtain the information to carry out the DNC in the companies of the year 2016 (graph 5), the incompatibility of schedules between the company and the students was the main one, adjustments were made in the schedules of the students, not It was possible on many occasions to coincide with the time when employees could give answers to the interviews. 
Which generated more time dedicated to obtaining information. And although the lack of financial resources of the interviewers is an important factor, it was not crucial because the problem could be solved.

\section{Resultas 2017}

The diagnoses made to 25 companies of preponderant turn of food and ceramic producer (graphic 6) the following data are obtained:

In this year, the 25 companies show that they require preparation in 68 different subjects, including those indicated in graph 7 , as follows: office, methodologies, tools, innovative learning strategies, administration, proper use of team management and work tools, planning didactics, group management, mathematical thinking, learning styles, learning strategies, stress management, quality of service, painting techniques, self-improvement, food and drinks among others. The main limitations to obtain the 2017 data, were little availability of companies to receive students and provide information and that companies are not near the university area, so the time of transfer and transport caused problems to the students to be on time in their appointments, as well as to collect the data at the agreed time, because once there it was difficult to find the owner or employees to collect the information according to the data in graph 8 .

\section{Results 2018}

As shown in Figure 9, the diagnosis was made to 20 companies of the predominant turns: food, services (health, public) and ceramic producers, the following data are obtained. In this year the 20 companies participating in the DNC, show preparation in 51 different topics including those indicated in figure 10, among which they continue to stand out: teamwork, customer service, leadership, safety and hygiene, and with less mention the courses of: communication, sales, marketing and accounting.

In graphic 11, it is observed how the lack of time of the collaborators of the companies is a limitation so that the diagnostic information can be obtained in time and form, and although the businessmen are the first interested in the DNC, We can observe how their lack of time as the main heads of business is an important limitation for the collection of information.

\section{Results 2019}

Derived from the diagnosis made to 21 companies of predominant food business as shown in graph 12 , the following information is obtained:

In the year 2019, the main need for training in the 21 participating companies is: safety and hygiene and customer service, although in a smaller amount they manifest needs due to teamwork, leadership, communication and first aid. Other more specific topics of the work area are: purchases, protective equipment, motivation, payroll and benefits, human relations, integration activities, work-related illnesses, evacuation and rescue, maintenance, work risks and customer service. In total, they say they need 17 different topics, including those mentioned, as shown in graph 13. The main limitation this year, according to figure 14, was the lack of availability to participate, as well as the lack of time to make the school schedule compatible with the company's schedule, as well as little time to get the answers from the staff.

\section{Analysis}

In companies it is sometimes difficult to train their workers due to multiple factors, one of them is the lack of financial resources, so when preparing their training plans and programs they must establish priorities.

Priority.

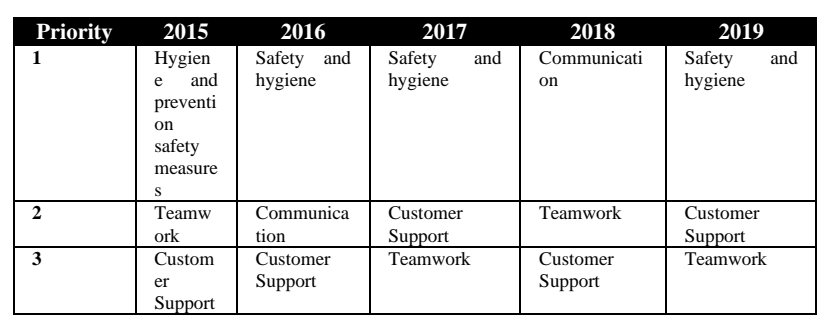

Table 3 Course priorities per year

Source: self made (2019)

This is shown in Table 3, that the topic on safety and hygiene for 4 years has been a priority, only in 2018 the course that was most needed was communication. In the case of teamwork and customer service courses, they have always occupied position two or three, as can be seen. 
Most Required Courses, Historical.

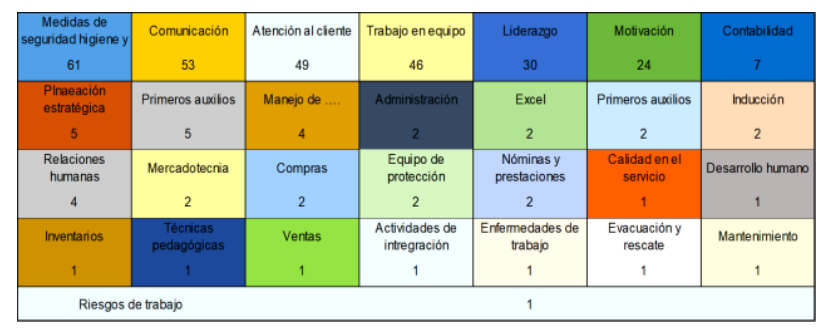

Table 4 Most required courses in 5 years

Source: own elaboration 2019

The main courses throughout these 5 years have been safety and hygiene measures, Communication, Customer Service, Teamwork, leadership and Motivation as shown in table 4; With the largest number of requests. In terms of general needs, the courses that have been most requested in the organizations each year and that the employees of the MyPEs require, without considering the priority, have been:

\begin{tabular}{|l|l|l|l|l|}
\hline \multicolumn{1}{|c|}{$\mathbf{2 0 1 5} 2016$} & \multicolumn{1}{c|}{2017} & \multicolumn{2}{c|}{2018} \\
\hline $\begin{array}{l}\text { Hygiene } \\
\text { and } \\
\text { prevention } \\
\text { safety } \\
\text { measures }\end{array}$ & $\begin{array}{l}\text { Safety and } \\
\text { hygiene }\end{array}$ & $\begin{array}{l}\text { Safety and } \\
\text { hygiene }\end{array}$ & $\begin{array}{l}\text { Safety and } \\
\text { hygiene }\end{array}$ & $\begin{array}{l}\text { Safety and } \\
\text { hygiene }\end{array}$ \\
\hline Teamwork & Teamwork & Teamwork & Teamwork & Teamwork \\
\hline $\begin{array}{l}\text { Customer } \\
\text { Support }\end{array}$ & $\begin{array}{l}\text { Customer } \\
\text { Support }\end{array}$ & $\begin{array}{l}\text { Customer } \\
\text { Support }\end{array}$ & $\begin{array}{l}\text { Customer } \\
\text { Support }\end{array}$ & $\begin{array}{l}\text { Customer } \\
\text { Support }\end{array}$ \\
\hline $\begin{array}{l}\text { Communic } \\
\text { ation }\end{array}$ & $\begin{array}{l}\text { Communic } \\
\text { ation }\end{array}$ & $\begin{array}{l}\text { Communic } \\
\text { ation }\end{array}$ & $\begin{array}{l}\text { Communic } \\
\text { ation }\end{array}$ & $\begin{array}{l}\text { Communic } \\
\text { ation }\end{array}$ \\
\hline Motivation & Motivation & Motivation & Motivation & Motivation \\
\hline Leadership & Leadership & Leadership & Leadership & Leadership \\
\hline
\end{tabular}

Table 5 Courses that are most historically detected Source: own elaboration 2019

Thus, employees are concerned about improving the work environment and physical conditions, making the facilities, equipment and work tools they use to carry out their activities safer. Very few companies request technical courses to improve specifications or elaboration. of their product or service, for example, in educational institutions if they request courses in educational psychology, pedagogy and didactics or in the paint ceramics industry, but they are few, since they are aware that the client must be well treated and that communication and teamwork make a difference in the work environment, according to the information presented in table 5. Finally, it is compiled that the main limitations have been, mainly the lack of time to collect the DNC data, the lack of availability of employees and employers to facilitate the information, lack of time to collect the data and mainly that the location of the company be far away as shown in graph 15 .

\section{Conclusions}

Switching to a more humanistic approach to training and staff development will allow companies to be more productive, optimize resources, make improvements, progress or evolve along with people. The training not only generates changes in the optimization of resources but also allows countries, companies or people to progress or evolve by changing the quality of life, the way people behave and behave, the awareness and training of them, that is why, when the 3 elements that are government, education and business manage to coordinate will contribute significantly to the development of the individual and society. Workers must also assume their responsibility in the process of improving as individuals, if there is no provision on their part the results of improvement will not be observed in the short, medium and long term. The diagnosis of training needs will allow organizations to focus their efforts and resources towards the specific area of knowledge necessary to improve the performance of their employees and collaborators, thus ensuring their enthusiastic participation in training and continuous improvement. Focusing the training on the specific requirements of each position, allows to increase the morale of the employees, increases their membership with the company and professionalize their work, increases their confidence, motivates them and generates confidence in their daily activities improving their performance.

\section{References}

Coelho, F. ( s. f. ). Desarrollo. Recuperado de https://www.significados.com/desarrollo/

Definición. de (2019). Crecimiento. Recuperado dehttps://definicion.de/crecimiento/

Grados, Jaime A. (2007), Capacitación y desarrollo de personal. México. Trillas.

Pinto, R. (2000). Planeación estratégica de Capacitación. México: Mc. Graw Hill

Siliceo, A. (2006). Capacitación y Desarrollo de personal. México: Limusa.

STPS, (2012). Ley Federal del Trabajo. Recuperado de

http://www.stps.gob.mx/bp/secciones/junta_federal/ secciones/consultas/ley_federal.html. 